\section{STUDIES ON THE DIFFERENTIATION INDUCERS OF MYELOID LEUKEMIC CELLS \\ II. CITRININ, A NEW INDUCER OF THE DIFFERENTIATION OF M1 CELLS}

\author{
Akira Kawashima, Masaya Nakagawa, \\ Yoichi Hayakawa, Hiroyuki KawaI, \\ Haruo Seto and Noboru ŌTake \\ Institute of Applied Microbiology, \\ The University of Tokyo, \\ Bunkyo-ku, Tokyo 113, Japan
}

(Received for publication November 17, 1982)

In the course of our screening program for inducers of myeloid leukemic cell differentiation ${ }^{1)}$, we have recently isolated citrinin as an active substance from the culture filtrate of a fungus, Monosporascus cannonballus. Citrinin induced the differentiation of mouse myeloid leukemic cells $(\mathrm{M} 1)^{2}$.

The fungus was cultivated in 500-ml Erlenmeyer flasks containing a Raulin-Thom medium $(100 \mathrm{ml})$ at $27^{\circ} \mathrm{C}$ for 7 days.

The filtrate of the fermentation broth (1 liter) was extracted twice with $500 \mathrm{ml}$ of ethyl acetate at $\mathrm{pH} 2$. The organic layer was back extracted twice with $5 \%$ sodium bicarbonate $(500 \mathrm{ml})$. The aqueous layer was subsequently adjusted to pH 2 and extracted with $500 \mathrm{ml}$ of ethyl acetate. The solvent layer was concentrated in vacuo to a small volume and the active material was obtained as yellow needle crystals (1).

The ${ }^{1} \mathrm{H}$ and ${ }^{13} \mathrm{C}$ NMR spectra (Fig. 1 and Table 1) indicated the presence of $=\mathrm{C}-\mathrm{CH}\left(\mathrm{CH}_{3}\right)-$ $\mathrm{CH}\left(\mathrm{CH}_{3}\right)-\mathrm{O}-\left(\delta_{\mathrm{H}}\right.$ in $\mathrm{CDCl}_{3} ; 1.23(3 \mathrm{H}, \mathrm{d}, J=$ $6.5 \mathrm{~Hz}), 1.35(3 \mathrm{H}, \mathrm{d}, J=6.5 \mathrm{~Hz}), 2.98(1 \mathrm{H}, \mathrm{dq}$, $J=6.5,<1 \mathrm{~Hz}), 4.78(1 \mathrm{H}, \mathrm{dq}, J=6.5,<1 \mathrm{~Hz}))$, $\mathrm{CH}_{3}-\mathrm{C}=\mathrm{C}-\left(\delta_{\mathrm{H}} ; 2.02(3 \mathrm{H}, \mathrm{s})\right)$, one olefinic proton $\left(\delta_{\mathrm{H}} ; 8.24(1 \mathrm{H}, \mathrm{s})\right)$, chelated phenolic $\left(\delta_{\mathrm{H}}\right.$; $15.88(1 \mathrm{H}, \mathrm{s}))$ and carboxylic protons $\left(\delta_{\mathrm{H}} ; 15.12\right.$ $\left(1 \mathrm{H}\right.$, br. s)). $\mathrm{UV}_{\max } 238$ and $340 \mathrm{~nm}$ in $0.1 \mathrm{~N}$ $\mathrm{HCl}$ - methanol. Based on these data, 1 was strongly suggested to be citrinin. This was proved by the ${ }^{13} \mathrm{C}$ NMR spectral data which were identical with literature values ${ }^{3)}$ and finally confirmed by direct comparison with authentic citrinin.

The effect of citrinin on the differentiation of
Table 1. ${ }^{13} \mathrm{C}$ NMR spectral data of $\mathbf{1}$ in $\mathrm{CDCl}_{3}$.

\begin{tabular}{cr}
\hline Carbon & $\begin{array}{c}\text { Chemical shift } \\
(\mathrm{ppm})\end{array}$ \\
\hline 1 & 162.6 \\
3 & 81.6 \\
4 & 34.5 \\
$4 \mathrm{a}$ & 139.0 \\
5 & 122.9 \\
6 & 183.6 \\
7 & 100.2 \\
8 & 177.1 \\
$8 \mathrm{a}$ & 107.3 \\
9 & 18.1 \\
10 & 9.3 \\
11 & 18.4 \\
12 & 174.4 \\
\hline
\end{tabular}

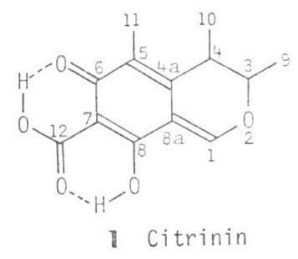

Table 2. Effect of citrinin on the growth and induction of phagocytic activity of M1 cells.

\begin{tabular}{ccc}
\hline $\begin{array}{c}\text { Citrinin } \\
(\mu \mathrm{g} / \mathrm{ml})\end{array}$ & $\begin{array}{c}\text { Phagocytic } \\
\text { cells }(\%)\end{array}$ & $\begin{array}{c}\text { Number of } \\
\text { cells } \\
\text { (cells/ml) }\end{array}$ \\
\hline 0 & 0.8 & $1.7 \times 10^{6}$ \\
5.0 & 0.9 & $1.3 \times 10^{6}$ \\
10.0 & 9.0 & $1.2 \times 10^{6}$ \\
20.0 & 37.8 & $5.8 \times 10^{5}$ \\
25.0 & 0 & 0 \\
\hline
\end{tabular}

M1 cells at $1.5 \times 10^{5}$ cells $/ \mathrm{ml}$ were incubated with various concentrations of citrinin for 72 hours and then their phagocytic activities were examined.

Table 3. Effect of citrinin on the growth and the rate of benzidine positive cells of B8 cells.

\begin{tabular}{ccc}
\hline $\begin{array}{c}\text { Citrinin } \\
(\mu \mathrm{g} / \mathrm{ml})\end{array}$ & $\begin{array}{c}\text { Benzidine } \\
\text { positive } \\
\text { cells }(\%)\end{array}$ & $\begin{array}{c}\text { Number of } \\
\text { cells } \\
(\text { cells } / \mathrm{ml})\end{array}$ \\
\hline 0 & 0.1 & $2.8 \times 10^{6}$ \\
5.0 & 0.4 & $2.7 \times 10^{8}$ \\
10.0 & 19.1 & $1.6 \times 10^{8}$ \\
15.0 & 39.5 & $4.0 \times 10^{5}$ \\
20.0 & 40.0 & $4.0 \times 10^{5}$ \\
30.0 & 0 & 0 \\
\hline
\end{tabular}

B8 cells at $3.0 \times 10^{5}$ cells $/ \mathrm{ml}$ were incubated with various concentrations of citrinin for 4 days. 
Fig. 1. ${ }^{1} \mathrm{H}$ NMR spectrum of $\mathbf{1}\left(400 \mathrm{MHz}\right.$ in $\left.\mathrm{CDCl}_{3}\right)$.

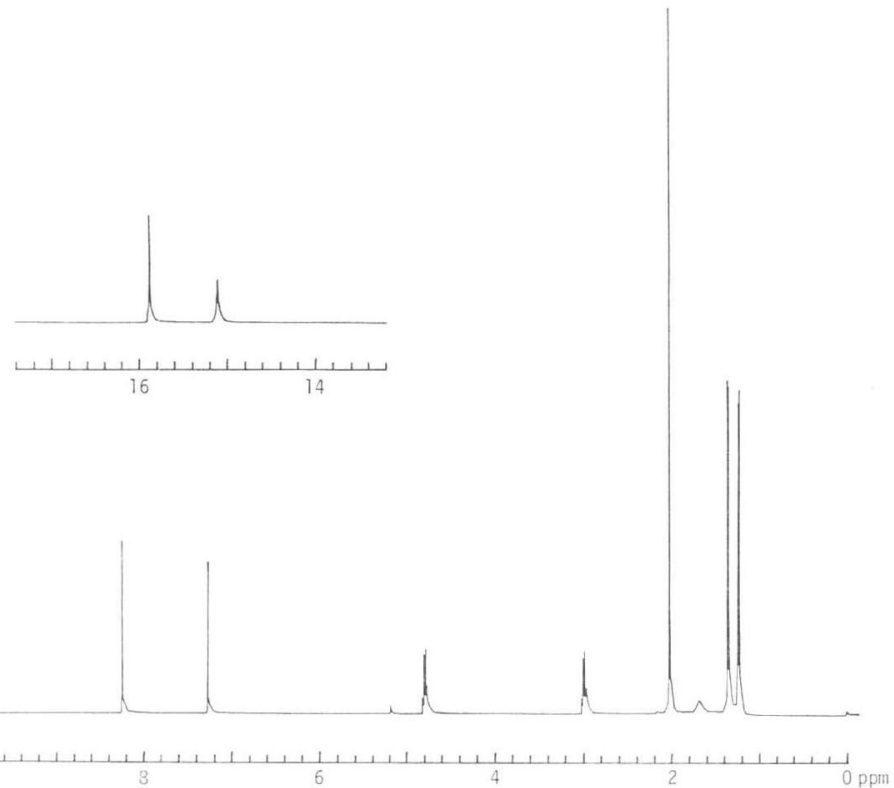

M1 cells were examined. On treatment with 1 $30 \mu \mathrm{g} / \mathrm{ml}$ of citrinin for $1 \sim 3$ days, the cells were induced to phagocytize latex beads and to synthesize lysozyme. Table 2 shows the phagocytic activity induced by various concentrations of citrinin for 3 days. The morphology of the cells changed into myelocyte during treatment with $20 \mu \mathrm{g} / \mathrm{ml}$ of citrinin for 3 days. Citrinin also induced the cell differentiation of mouse erythroleukemic cells (B8) into benzidine positive cells. Table 3 shows the rate of benzidine positive cells induced by various concentrations of citrinin for 4 days. On the other hand citrinin showed no effect to the differentiation of human promyelocytic cells (HL-60).

Citrinin is known to be active against Grampositive bacteria and to possess carcinogenic activity ${ }^{4}$. Further studies on the biological activity of citrinin are in progress.

Acknowledgment

We wish to thank Prof. Y. IcHJKAwA, Kyoto Univer- sity, Dr. M. Hozumi, Saitama Cancer Center Research Institute and Prof. M. OISHI, Institute of Applied Microbiology for providing us with the leukemia lines used in this study, and Dr. T. WATANABE, National Institute of Agricultural Sciences for providing us with Monosporascus cannonballus.

\section{References}

1) Hayakawa, Y.; M. Nakagawa, T. Andō, A. Shimazu, H. Seto \& N. Ōtake: Studies on the differentiation inducers of myeloid leukemic cells. J. Antibiotics 35: 1252 1254, 1982

2) IchiKaWA, Y.: Differentiation of a cell line of myeloid leukemia. J. Cell. Physiol. 74: 223 234, 1969

3) Sankawa, U.; Y. Ebizuka, H. Noguchi, Y. Ishikawa, S. Kiyagawa, T. Kobayashi \& H. Seto: Biosynthesis of citrinin in Aspergillus terreus incorporation studies with $\left(2-{ }^{13} \mathrm{C}, 2-{ }^{2} \mathrm{H}_{3}\right)$, $\left(1-{ }^{13} \mathrm{C},{ }^{18} \mathrm{O}_{2}\right)$ and $\left(1-{ }^{13} \mathrm{C},{ }^{17} \mathrm{O}\right)$ acetate. Heterocycles 16: 1115 1118, 1981

4) Ueno, Y.: Chemistry and biological activity of mycotoxins. Igaku no Ayumi (in Japanese) 112: $960 \sim 970,1980$ 